\title{
AUSTRALIAN LAND PLANARIANS: DESCRIPTIONS OF NEW SPECIES AND NOTES ON COLLECTING AND PRESERVING.
}

No. 2.

By Thos. Steel, F L.S., F.C.S.

(Plate xxxiv.)

Part i.-Descriptions of new species, de.

Since the publication of my previous paper on Australian Land Planarians (11, p. 104)* I have obtained several interesting undescribed species, descriptions of which, with other notes, are contained in this paper.

For specimens of the following species from Western Australia I am indebted to Mr. Chas. G. Hamilton, who collected and sent them to me preserved in spirit. They are of particular interest as being the first recorded land planarians from that part of Australia, and from the fact of two of the species being found living in a dry sandy district which would be considered extremely unfavourable for such creatures.

In describing these land planarians I have thought it best to adhere to the old generic classification in the meantime, though Prof. von Graff, in his recently published great monograph of the group, (12) has proposed the new genus Artioposthia for a number of species which have hitherto been included in the genus Geoplana.

Some points in Graff's arrangement of these may require modification, through, amongst other reasons, his not having had an opportunity of examining specimens of some of the species. At

*The numbers in brackets refer to the Bibliography at the end of the paper. 
a future date I propose to deal with all the described Australian forms in detail, so as to, as far as possible, bring into accord the work of different observers.

The type specimens of all the species described in this paper are deposited in the Australian Museum, Sydney.

\section{Geoplana Fusco-Dorsalis, n.sp.}

$$
\text { (Pl. xxxiv., fig. 1.) }
$$

Ground colour of dorsal surface uniform dark grey, with a narrow median line of pale grey. Anterior tip brown. Ventral surface uniform rich cream colour. Eyes numerous, single row round anterior tip, then very thickly grouped in about seven horizontal rows extending for at least 8 to $9 \mathrm{~mm}$. backwards. Length of spirit specimens $50 \mathrm{~mm}$. by $4 \mathrm{~mm}$. at widest part.

The peripharyngeal opening $27 \mathrm{~mm}$. from anterior tip; genital opening not clearly distinguishable.

Hab. - Near Perth, Western Australia; under chips, \&c. (Mr. Chas. G. Hamilton).

The above are the colours as noted from the living specimens by Mr. Hamilton. In spirit they remain apparently unaltered.

In general shape this planarian belongs to the group of which G. quinquelineata, Fletch. \& Hamil., may be taken as representative, being somewhat rounded in section and tapering gradually to anterior tip and somewhat abruptly to posterior end.

\section{Geoplana arenicola, n.sp.}

$$
\text { (Pl. xxxiv., fig. 2.) }
$$

Dorsal surface : general aspect umber brown with a dark narrow median line. On close inspection the surface is seen to be covered very closely with umber brown dots, among which the pale brown body colour shows. Anterior tip very dark brown.

Ventral surface pale grey covered with brown dots. These tend to arrange themselves in four bands. One band is on either side of the median space, which is either free from dots or but 
thinly sprinkled. Then there is a similar clear or partially dotted space, and then a band of dots closely crowded together to form a continuous margin. Eyes large, closely set in a crowded row round anterior tip, then densely grouped at sides extending for several $\mathrm{mm}$.

Length of spirit specimen $34 \mathrm{~mm}$. by $4 \frac{1}{2} \mathrm{~mm}$. wide. Peripharyngeal opening $14 \mathrm{~mm}$. from tip; genital aperture not visible. Another specimen $33 \mathrm{~mm}$. long, also has the peripharyngeal opening $14 \mathrm{~mm}$. from tip. In two specimens which I believe to be the young of this species, there is a dark dorso-median line composed of aggregated speckles, and a dense black-brown broad marginal band, the space between being uniformly sprinkled with large speckles. Ventral surface is similar to that of the adult. The length of these is 12 and $13 \mathrm{~mm}$. respectively.

Hab.-Near Perth, Western Australia; under chips and bark. (Mr. C. G. Hamilton).

This species in shape resembles G. Fletcheri, Dendy, its section and outline being very similar.

Referring to the habitat of the above two species, Mr. Hamilton writes me as follows:-

"I cannot make out where they go in the dry season-with us about 8 months. I suppose they must burrow into the sand, but if so they must dig pretty deep, for the sand is quite hot and dry for at least a couple of feet down in summer."

This is a problem that has long puzzled me in common with other observers of our land planarians. Knowing how intolerant these creatures are of dry conditions when removed from their lurking places, it is not easy to imagine how they contrive to survive the baking to which the ground is subjected-to say nothing of the disastrous bush fires-during the frequent long periods of drought in Australia.

Darwin (1, p. 242) collected species in La Plata and Chili living under arid conditions in small earth chambers, and Dendy (7, p 67) has noted the formation of earth cysts by Australian land planarians, in which they remained completely enclosed. 
Geoplana melanochroa, n.sp.

(Pl. xxxiv., fig. 3.)

Specimen in spirit. Dorsal surface uniform black. Ventral surface black at margins, with a pale central band of about onethird of the total width. The whole ventral surface has a purple tinge.

Eyes quite invisible until a specimen was cut in sections, when they were found to extend in a single row round anterior tip and right down the sides in a sparse row without side grouping, but with an occasional straggler out of the line.

Length $16 \mathrm{~mm}$. by $1 \frac{1}{2} \mathrm{~mm}$. in width. Peripharyngeal aperture $9 \mathrm{~mm}$. from anterior tip, with genital opening $12 \frac{1}{2} \mathrm{~mm}$., or just midway between peripharyngeal aperture and posterior end.

Hab.-Armadale, Darling Ranges, Western Australia; in ightly timbered country, in sheltered gullies, under pieces of ironstone (Mr. C. G. Hamilton).

This curious little planarian bears some resemblance to $G$. atrata, mihi, (11, p. 105) but is readily distinguished by the absence of the black ventro-median line, and by the greater width of the black marginal bands on same surface.

\section{Geoplana graminicola, n.sp.}

$$
\text { (Pl. xxxiv., fig. 9.) }
$$

General colour of dorsal surface red-brown. The whole surface covered with specklings of a darker red-brown which tend to collect into an irregular median band, most distinct towards the posterior end. In some specimens the specklings are very thinly distributed, making the dorsal surface much paler than usual, and in a few they are so densely packed as to impart a uniform dark brown tint.

Ventral surface pale, with no markings except near the anterior tip, where there are a few specklings similar to those on dorsal surface. Eyes few but conspicuous. In a single row round the anterior tip and for a short distance down the sides, spaced some- 
what widely apart. No side grouping. Length when crawling 13 to $18 \mathrm{~mm}$. by less than $1 \mathrm{~mm}$ in width.

In a spirit preserved specimen which is $16 \mathrm{~mm}$. in length, the peripharyngeal aperture is $9 \mathrm{~mm}$. from the anterior end and the genital opening $12 \frac{1}{2} \mathrm{~mm}$.

Hab.-Petersham, near Sydney; common in my garden living amongst grass. I got this elegant little planarian feeding on dead slugs which I had casually left under a damp sack lying on grass in the shade of my house. By keeping up this mode of trapping them I secured specimens during the greater part of the year, but they are most abundant in the summer months. During October and November, 1889, on a very limited area of ground, some five or six square yards, I captured under sacks over 200 individuals.

I have not met with this species anywhere else, but if, as is certainly the case in my garden, it burrows amongst the roots of grass, it might readily be overlooked. It may possibly be an introduced form, though I have failed to find a description of it in Prof. von Graff's monograph before-mentioned. The species which appears to come nearest to it is Geoplana gamblei, Graff, from North Celebes, but differs in being several times larger and in having a sharply defined dorso-medial band.

Geoplana scaphoidea, nom.nov.

Geoplana elegans, Steel (11, p. 111, Pl. vi., fig. 2); non Planaria elegans, Darwin, (1, p. 244); non Geoplana elegans, Darwin, Müller and Schultze, (2, p. 29); non $G$. elegans, Darwin, Graff, (12, p. 328).

When I gave the name $G$. elegans to a land planarian from Queensland, I was unaware that it was preoccupied by Darwin for a species from Rio de Janeiro, and having since ascertained the fact, I now desire to re-name the species as above.

Geoplana quinquelineata, Fletch. \& Hamil., var.nov.

The typical G. quinquelineata (Pl. xxxiv., fig. 7) has the lines varying greatly in different individuals in intensity of 
colour, but all diffuse and with ill-defined margins. They are spaced at about equal distances apart. The median line is if anything. usually slighter and less strongly marked than the others. In G. quinquelineata, var. accentuata, mihi (11, p. 110, pl. vii., fig. 7) the equal spacing of the lines is preserved, the variety differing from the species merely in having the median line accentuated.

As showing the variation in the character of the lines, Pl. xxxiv., fig. 8, illustrates a specimen of G. quinquelineata from Milton, N.S.W., collected and given to me by Mr. W. W. Froggatt, F.L.S. This example has all the lines broad and diffuse, almost confluent, and with very narrow spaces of body colour between.

$H a b$ - - Adelaide, S.A., (one perfect, and several damaged specimens; Mr. J. W. Mellor); Armadale, Darling Ranges, West Australia (two spirit specimens; Mr. C. G. Hamilton).

Note.-For a reconsideration of the identity of this species, see postscript, p. 577 .

Part ii.- Notes on habits, collection and preservation.

(a). Habits._Since the publication of my former paper on Land Planarians, I have received from friends desirous of aiding in the study of these creatures, numerous enquiries as to their mode of occurrence, habits, \&c., and for the purpose of disseminating information on these points, I have thought it well to include in this paper the following notes:-

Land planarians are to be met with in Australia chiefly under $\operatorname{logs}$ and pieces of wood lying about in paddocks adjacent to scrub. In the scrub itself they are not so readily found because of the larger amount of available shelter, and because the insects on which they prey are more abundant under the logs in the open. Like other creatures of similar habits they are found most plentifully where the soil is rich, this fact doubtless being due to the more fertile land supporting a larger insect population, and, therefore, providing a better supply of food than is present in 
less favourable districts. Perhaps conditions of moisture also favour the good land, for fertile soil usually retains moisture better than that which is poor, and so preserves better during dry weather the conditions necessary for the existence of land planarians. During wet weather they are to be met with under leaves, and even crawling about in the open in daylight, and in lurking places less secure than those afforded by the shelter of $\operatorname{logs}$, but in a general way the collector must rely on the $\operatorname{logs}$, as it is under them he will meet with the largest proportion of his finds. Several species favour shady gullies, but as a rule few will be met with on land which is very damp or swampy. Some species burrow freely and seem as much at home in the soil associated with earthworms as under logs. In Fiji my brother, Mr. F. W. Steel, F.C.S., found Rhynchodemus scriptus and Geoplana trifasciata, mihi, burrowing in a compost heap, and he has recently sent me from Yarraville, near Melbourne, a number of specimens of $G$. sanguinea, Moseley, which he found in the soil while digging his garden. I have myself also met with the same species in a similar situation in the suburbs of Sydney.

Several naturalists have recorded their observations on the food of these worms. Darwin, who kept some specimens in captivity, found that they increased in size without access to any food save some decayed wood, and from this he suspected that they fed upon this substance (1, p. 242).

Moseley (3, p. 112) suggests that the increase in size noted by Darwin was really due to cannibalism, and quotes the evidence of Max Schultze, who examined the digestive tract of a Geoplana and found no trace of vegetable matter, but only the palate and jaws of a snail. Moseley further quotes Fr. Müller and Leidy, the former of whom found a blind species named Geobia sutterranea, Fr. Müll., in Brazil, living in the burrows of an earthworm on which it preyed, while the latter observer fed a Rhynchodemus on house flies. Finally, Moseley himself carefully examined sections of four species of Ceylon land planarians without in any case detecting a trace of vegetable matter in the intestines. 
Brittlebank (5, p. 48) records instances in which he observed land planarians in Victoria, feeding on, in one case, a wood-louse, and in the other the larva of a beetle. Dendy also found a Geoplana in the act of preying on a beetle, $(6$, p. $132 ; 7$, p. 68 ; and 9, p. i 16).

Spencer $(\mathbf{1 5}$, p. 86) speaks of the voracity of land planarians in general, and of $G$. Spenceri, Dendy, in particular, he having seen this species catch and suck the inside out of a beetle.

Quite recently Scharff (13, p. 33), in describing a new European Rhynchodemus of extremely large size, mentions the fact of his finding it feeding upon a snail. A remarkable feature about this species as figured is the unusually far forward position of the apertures.

For some years past I have myself had numerous opportunities of studying land planarians in a state of nature and in captivity, and I have on very frequent occasions seen them feeding on insects of various kinds, earthworms, slugs, Peripatus, dc., and one species on another; but I have never seen one attempt to eat vegetable matter of any kind, either fresh or decayed. The suctorial oral tube, while eminently well adapted for imbibing the juices and soft tissues of insects, \&c., is not at all suited for the ingestion of vegetable fibre or decayed wood, and I think that there can be no doubt that Moseley's explanation of Darwin's observation is correct.

Under favourable conditions of moisture and temperature they are able to live for many months without food, but under such circumstances they become sluggish and move about very little.

Their method of securing their prey is to crawl over it and thus entangle it with the sticky mucus which is freely secreted over the surface of their bodies. The trumpet-like suctorial tube is then protruded from the peripharyngeal aperture and inserted in the captive's body, and the soft contents of the latter quickly transferred to the alimentary canal of the planarian. Even Peripatus, with its active habits and elaborate slime-shooting appliance, falls an easy prey to the larger planarians, and when collected should always be put in a separate box. 
In those land planarians possessing more than two eyes, these organs are usually very numerous, amounting in some cases to several hundred. They consist of minute black dots, only occasionally sufficiently large to be visible to the naked eye, extending in a single row round the edge of the anterior tip usually expanding into a more or less crowded group on each side just behind the tip, and then thinning out again to a single row on either side which may extend right down to the posterior end. In some species there is little or no side grouping, the eyes being arranged in a single row extending backwards to a variable distance. Those planarians possessing two eyes only (Rhynchodemus, \&c.), have them situated one on each side, just behind the anterior tip. The eyes appear to be merely sense organs serving to distinguish light from darkness, thereby enabling the animal to avoid the light when it so desires. I do not believe that the eyes possess any degree of true vision in the sense of enabling the planarians to distinguish objects.

As pointed out by Dendy (10, p. 42) the eyes may be well displayed by crushing the anterior tip of a living specimen between a glass slip and coverglass, and examining under the microscope. Small or young individuals may also be prepared by soaking in oil of cloves, after previous preparation in strong spirit, when they become translucent, and when mounted in Canada balsam show the eyes to great adrantage, besides giving an excellent view of the alimentary canal and some other interesting details of structure.

When moving about they hold up the anterior end, curving the sides downwards so that a cross-section would have the outline of a horseshoe, and delicately sweep the tip about, gently touching any objects that may be in the way. If a small article dipped in weak spirit, or the finger be held near the tip, they become aware of its presence without coming in contact with it, and quickly turn away so as to avoid it. Doubtless the ciliated pits situated in a row beneath the eyes at this part, serve, as suggested by different observers (3, p. 145; 8, p. 44), as olfactory 
organs. By their aid the worm probably becomes aware of the presence of objects to be avoided and also of its prey.

Though land planarians are properly nocturnal in their habits, some species are by no means adverse to moving about in daylight during dull, moist weather. I have specially noted this habit in the case of Geoplana corulea, Moseley, which I have found at Wentworth Falls and elsewhere actively crawling along by day. My brother, Mr. John S. Steel, has noticed the same fact about this species at Mount Bauple in Queensland. Dendy has recorded the occurrence of the same habit in other species, notably G. Sugdeni, Dendy.

The tenacious slime which is so freely secreted all over the body surface is no doubt of service as a protection from possible enemies by rendering them unpalatable, as well as constituting an important means of capturing their prey.

Dendy has recorded his observations on the rejection of living planarians by domestic fowls (7, p. 69). I have noticed that fowls will readily eat planarians which have had the slime coagulated by preservation in spirit. This treatment would, of course, by coagulation, completely neutralize the objectionable properties of the slime.

Land planarians are, of course, hermaphrodite, the $q$ and $\hat{\delta}$ organs opening into a common genital atrium, the external orifice of which is situated on the ventral surface behind the peripharyngeal aperture, at a distance from it varying in different species. While the latter aperture is usually readily detected in spirit preserved specimens, the genital opening cannot always be seen, being most conspicuous about the breeding season, while at other times it may be very small and obscure. Specimens are frequently met with having a large swelling just behind the genital aperture, caused by the presence of an egg-capsule. This is a round or somewhat oval body, having a hard chitinous shell, smooth and shining, and of a brown colour while in the uterus and for a day or so after laying, but turning to shining jet black after that. 
So far as I have been able to ascertain by reference to literature, Dendy is the only observer so far who has noticed the method of laying the egg-capsule. He describes the presence of a large aperture in the back of a specimen of Geoplana triangulata, Dendy, after the event (9, p. 116). Commenting on this, Graff (12, pp. 239-240, footnote) merely remarks that he supposes we have here to do with a rupture of the dorsal wall of the genital atrium.

The egg-capsule in some species attains large dimensions. I have an example of that of $G$. Spenceri, Dendy, which is 10 by $7 \mathrm{~mm}$.

Although I have occasionally found egg-capsules laid in my vivaria by captive specimens, I have not until recently been able to confirm Dendy's observation on this curious habit. For the opportunity of doing so I am indebted to Mr. H. Stuart Dove, of Launceston, Tasmania, who sent me a fine specimen of G. Mortoni, Dendy. When the specimen reached me it had just deposited the capsule, which was still of a fresh brown colour. On the dorsal surface of the worm, just behind the position of the genital opening, was a rent or tear of the tissues through which projected the peculiar comb-like lobes of the genital organs. The protrusion of these shows that the dorsal wall of the genital atrium is torn to permit of the exit of the capsule.

Pl. xxxiv., fig. 10, shows the appearance of this interesting specimen. The opening caused by the exit of the capsule appears to heal very quickly, certainly within two or three days, as otherwise I must have noticed it on other occasions.

In writing to me regarding a specimen of $G$. Dovei, mihi, which was about to deposit a capsule, Mr. Dove specially mentioned that the integument on the dorsal surface just over the capsule was very tense and appeared ready to give way, and other observers besides myself have noticed the same appearance. From these facts and the obvious improbability of the large capsule being able to make its exit through such a small passage as the genital opening, I am inclined to think that Dendy's 
surmise as to the above being the normal mode of laying is correct.

The period of incubation for the egg-capsule after laying appears to be very variable. I have seen some hatch after being laid a few days only, while others have remained for seven to eight weeks in the vivarium before the young emerged.

(b). Collection and preservation.-When collecting land planarians they are best put into small tin boxes or wide-mouthed bottles, the covers or corks of which fit fairly close, but are readily removed. These should be loosely filled with fresh leaves such as those of docks, dandelions, fresh moss or such like, but anything wet, or aromatic leaves, should be avoided In such boxes of leaves they will live for a considerable time in cool weather, and I have so carried them alive from New Zealand to Sydney and thence to Melbourne, and have received by post in Sydney from friends in Tasmania, Queensland, Victoria, and South Australia.

Though planarians can be fairly well preserved by putting them direct into ordinary methylated spirit, they are displayed to much greater advantage when prepared in the manner described below. When simply placed in spirit the slime with which their bodies are invested is at once coagulated, forming a dense opaque coating which more or less hides the bands and markings upon which we largely depend for the differentiation of species, besides usually concealing the eyes. In addition the animals are more or less twisted and distorted, making subsequent study difficult.

In preserving such soft-bodied creatures it is necessary to make use of a fluid medium, as they cannot be dried without destroying all recognisable characters.

I have made numerous experiments on the preservation of land planarians, but have not found any method to give better results than that described in my former paper and given in substance below. 
Formaline solution made by diluting 3 volumes of the strong formaline of commerce to 100 volumes with water, has proved an admirable preservative, and has the great advantage of not coagulating the slime like spirit. In a general way, however, I prefer the latter medium, as on the whole the results attained when it is properly used seem to me rather the more pleasing. Though formaline in some cases induces rather more colour change than spirit, and is a somewhat disagreeable medium when the specimens have to be much handled during examination, it may be used with confidence if preferred. When the specimens have to be preserved in the field, or the collector is unable to do more than put them direct into the preservative, formaline should be used. It should not be made any stronger than indicated above, and should be used plentifully.

In preserving these worms--and I may here state that earthworms, leeches, and slugs may be treated in precisely the same manner-I first of all kill them with weak spirit. The strength which I prefer is 1 of ordinary methylated spirit to 15 of water. The worms are dropped into plenty of this contained in a shallow dish, and die in 10 to 15 minutes without the slime becoming coagulated, or the worm becoming distorted or broken. I now take them up one at a time by means of a pair of weak-springed flat-bladed forceps, and with the aid of a damp cloth and my wetted fingers gently draw the blades of the forceps along the worm's body, slightly compressing the body between them, and in this way scrape off the slime, wiping the forceps on a piece of rag. With a little care this can be done readily and safely even with the most delicate planarians, and leaves them beautifully clean and free from the objectionable slime. It is necessary to keep the fingers moist, otherwise the worm will stick and become damaged.

Having the formaline or strong spirit ( 80 to 85 per cent.) in another shallow dish, the worm is gently laid in it, and by means of fingers and forceps flattened and straightened out and prevented from shrinking too much as the spirit hardens it. A few moment suffices for this, and it is now left while the others are 
being similarly treated. Finally the specimens are transferred with formaline or spirit to the tubes or bottles in which they are to be preserved. Small specimens are more conveniently handled during hardening in a pool of spirit poured on a sheet of flat glass. Specimens for histological purposes may after killing and cleaning as above, be laid out in corrosive sublimate solution in alcohol, allowed to soak for an hour or so, and then transferred to spirit. They may thus be obtained nicely straightened and in good order for cutting into sections.

In the paper before-mentioned I described experiments on the use of chloroform, kerosene, \&c., as preservatives, and it may be of interest to here record the results of these trials. Chloroform proved quite unsuitable, owing to its great volatility and want of hardening power. Kerosene, after prolonged contact, gradually displaced the water in the tissues, giving the specimens a translucent horny appearance, and completely spoiling them. The carbolised oil recommended by $\mathrm{Haly}^{*}$ as a general preservative, is a very messy medium, and of no use at all for planarians. I understand that Haly has now abandoned its use in favour of formaline. I have tried acetone, but the results of its use are in no way better than with spirit.

I cannot recommend any better medium than spirit, used as described above, or formaline if more convenient.

After the planarians have been preserved, it is absolutely necessary that they should be kept in total darkness, or it will only be a matter of time when they will be completely bleached and ruined. Before I became aware of this I lost a number of fine specimens by leaving them exposed to the light near a window for a few months, and I have seen a good many preserved specimens in museums and elsewhere totally spoiled from this cause.

The tubes containing the specimens should be placed in a wide-mouthed tightly closed jar with some spirit surrounding them. This prevents the drying up of the tubes through leakage

* A. Haly. Report Ceylon Museum, 1889, p. 12. 
of the spirit through the corks, and if the jar is placed in darkness, enables the specimens to be preserved indefinitely without any depreciation in colour. I mention this fact specially, as more than one of my friends who have preserved land-planarians have erroneously attributed loss of colour caused by exposure to light to bleaching by the spirit. Spirit, I have found by careful observation, will not cause any further alteration in colour after the fugitive body colour has been dissolved, if the specimens are kept in darkness. I have specimens preserved in this manner which have remained quite unchanged for seven or eight years.

In conclusion I desire to express my thanks to the friends already mentioned who have furnished me with specimens, to Professor W. A. Haswell, F.R.S., dc., for his kindness in giving me the use of his copy of Professor von Graff's Monograph, and to Mr. J. P. Hill, B.Sc., F.L.S., for histological and other assistance.

As it is extremely desirable that specimens of these interesting worms from as many parts of the colonies as possible should be secured for study and description, I shall be very pleased to hear from anyone willing to assist in the work of collection.

\section{Postscript (6th Oct., 1900).}

Geoplana mediolineata, Dendy, var. simularis, n.var.

$$
\text { (Pl. xxxiv., fig. 6.) }
$$

A few days after this paper was.read, I received from Mr. J. W. Mellor, of Fulham, near Adelaide, South Australia, a fine collection in a living state of the planarian of which I had only previously seen one perfect and several damaged specimens from near Adelaide, and two damaged examples from Western Australia, and which I had determined to be a variety of G. quinquelineata, Fletch. \& Hamil.

Mr. Mellor's collection includes a large and graduated series which clearly proves that the form in question is really a variety of G. mediolineata, Dendy; and I am desirous, therefore, of 
correcting the determination given above at the earliest opportunity. From a careful examination of all the specimens now available, I am satisfied that they belong to one species, and that its affinities are with $G$. mediolineata rather than with $G$. quinquelineata as I at first supposed.

The collection sent me by Mr. Mellor may be divided into three series as follows :-

(a). Typical specimens of $G$. mediolineata, Dendy, (7, p. 76, pl. vii., figs. 1-2, and this paper, pl. xxxiv., fig. 4), with bold median line as usual and the lateral diffuse lines at anterior tip running back for a short distance.

(b). Examples of Dendy's three-lined variety of the same species (loc. cit., p. 77, pl. vii., figs. 3-3a., and this paper, pl. xxxiv., fig. 5). The lateral lines extend in some individuals from end to end, while in others they fade out at varying distances back.

(c). A very distinct variety having five continuous dorsal lines (pl. xxxiv., fig. 6) and which constitutes the form which I propose to distinguish as $G$. mediolineata, var. simularis, to denote its resemblance to $G$. quinquelineata. From the latter species and its var. accentuata the present variety is distinguished by having the lines at unequal distances apart, the lateral lines being close to the median, while the marginal lines have about twice that space between them and the lateral lines, and are also about same distance from the margin. The median line is always strongly marked, the lateral lines are more diffuse, and the marginal lines usually as strongly pigmented as the median. The specimens received were of different lengths up to $140 \mathrm{~mm}$. when crawling. Two examples in spirit 112 and $85 \mathrm{~mm}$. in length have the peripharyngeal aperture $46 \frac{1}{2}$ and $36 \frac{1}{2} \mathrm{~mm}$. respectively from anterior tip. In none of the specimens is the genital opening visible.

Spencer (10, pp. 86 and 93, pl. xii., fig. 15) figures a variety of $G$. mediolineata which he considered intermediate between that species and $G$. quinquelineata. This I formerly thought might be a somewhat abnormal example of $G$. quinquelineata, var. accentuata, (11, p. 111), but in the light of present knowledge I now 
think it may be safely identified as an example of series $(b)$ as above.

Between these three forms there are numerous intermediate examples which carry us step by step from the typical $G$. mediolineata to the extreme var. simularis with five continuous lines. Several small specimens of var. simularis differ from the others in having all the lines diffuse, the spaces of body-colour closely speckled with brown, and the marginal lines distinctly split longitudinally so as to form seven lines in all, but these need not be specially considered, as they are obviously mere extreme variations.

All the specimens have the lines of a bright red-brown and anterior tip of same colour. The body-colour varies from bright sulphur-yellow to pale cream. Ventral surface white.

Hab.-Through the good offices of Mr. A. H. C. Zietz, F.L.S., \&c., of the South Australian Museum, I have received specimens from near Adelaide, South Australia; from Miss C. A. Selway, Gilberton; from Miss Eimer, found in her shade-house at Norwood; and, as already mentioned, from Mr. J. W. Mellor. Mr. C. G. Hamilton sent me from Armadale, Darling Ranges, Western Australia, in spirit, two specimens which, though somewhat damaged, I have no doubt belong to the new variety.

While dealing with the relationship of the above species, it may be well here to mention that Graff (12, p. 374, pl. v., figs. $15-16$ ) gives an account of specimens of $G$. quinquelineata from Victoria, sent to him by Dendy. His tig. 16 is the form which I named var. accentuata (loc. cit.), and fig. 15 is the same variety with broad diffuse paired stripes similar to those in the specimen from Milton, N.S.W., before mentioned.

\section{REFERENCES.}

1.-Darwin, C., Annals \& Mag. Nat. Hist., Vol. xiv., 1844.

2.-Mueller \& Schultze, "Beiträge zur Kenntniss der Landplanarien," Abh. d. Nat. Ges. zu Halle. 4r. Band, 1856.

3.-Moselex, H. N., Phil. Trans. Royal Soc. London, Vol. 164, 1873.

4.-Fletcher \& Hamilton, Proc. Linn. Soc. New South Wales, 1887. 
5.-Brittlebbank, C. C., Victorian Naturalist, Melbourne, Vol. v., 1889.

6.-Dendy, A., Victorian Naturalist, Vol. vi., 1891.

7.— Trans. Royal Soc. Victoria, Melbourne, 1890.

8.— Proc. Royal Soc. Victoria, Melbourne, 1891.

9.—— Report Aust. Assoc. Adv. Science, Vol. vi., 1895.

10.-Spencer, W. Baldwin, Proc. Royal Soc. Victoria, 1890.

11.-Steel, T., Proc. Linn. Soc. New South Wales, 1897.

12.-Graff, L. von, Monog. der Turbellarien. ii. Tricladida Terricola (Land planarien), Leipzig, 1899.

13.-Scharff, R. F., Journ. Linn. Soc. Zoology, London, Vol. xxviii., 1900.

\section{EXPLANATION OF PLATE XXXIV.}

Fig. 1.-Geoplana fusco-dorsalis. Dorsal aspect (nat. size).

Fig. 2.- , arenicola. a. Dorsal, $b$. ventral aspect $(\times 2)$.

Fig. 3.- , melanochroa. Ventral aspect $(\times 3)$.

Fig. 4.- ,, mediolineata. Dorsal aspect of typical form. a. Anterior portion, $b$. middle $(\times 4)$.

Fig. 5._ , mediolineata. Dorsal aspect of three-lined form, middle of body $(\times 4)$.

Fig. 6.- , mediolineata, var. simularis. Dorsal aspect, middle of body $(\times 4)$.

Fig. 7.- ,, quinquelineata. Dorsal aspect, typical form, middle of body $(\times 4)$.

Fig. 8.-- ,, quinquelineata. Dorsal aspect, diffuse-lined form, middle of body $(\times 4)$.

Fig. 9.- ,, graminicola. Dorsal aspect $(\times 3)$.

Fig. 10.- " Mortoni. Portion of dorsal surface showing rupture for exit of egg-capsule $(\times 4)$.

The outline under each figure represents the section of the body at the middle. 


\section{$2 \mathrm{BHL}$ Biodiversity Heritage Library}

Steel, T. 1901. "Australian land planarians: descriptions of new species and notes on collecting and preserving." Proceedings of the Linnean Society of New South Wales 25, 563-580. https://doi.org/10.5962/bhl.part.12175.

View This Item Online: https://www.biodiversitylibrary.org/item/30484

DOI: https://doi.org/10.5962/bhl.part.12175

Permalink: https://www.biodiversitylibrary.org/partpdf/12175

\section{Holding Institution}

MBLWHOI Library

\section{Sponsored by}

MBLWHOI Library

\section{Copyright \& Reuse}

Copyright Status: NOT_IN_COPYRIGHT

This document was created from content at the Biodiversity Heritage Library, the world's largest open access digital library for biodiversity literature and archives. Visit BHL at https://www.biodiversitylibrary.org. 